\title{
The effect of conditioning with $\mathrm{NaCl}, \mathrm{KCl}$ and $\mathrm{HCl}$ on the performance of natural clinoptilolite's removal efficiency of $\mathrm{Cu}^{2+}$ and $\mathrm{Co}^{2+}$ from $\mathrm{Co} / \mathrm{Cu}$ synthetic solutions
}

\author{
BB Mamba $^{1 *}$, DW Nyembe ${ }^{1}$ and AF Mulaba-Bafubiandi ${ }^{2}$ \\ ${ }^{1}$ Department of Chemical Technology, University of Johannesburg, PO Box 17011, Doornfontein 2028, South Africa \\ ${ }^{2}$ Minerals Processing and Technology Research Group, Department of Extraction Metallurgy, University of Johannesburg,
} PO Box 526, Wits 2050, South Africa

\begin{abstract}
Southern African clinoptilolite's capability as an ion-exchanger with respect to $\mathrm{Cu}^{2+}$ and $\mathrm{Co}^{2+}$ was investigated in order to consider its viability in the removal of metal cations from aqueous solutions. The effect of chemical conditioning was investigated using sodium chloride $(\mathrm{NaCl})$, hydrochloric acid $(\mathrm{HCl})$ and potassium chloride $(\mathrm{KCl})$. The most efficient activating or conditioning reagent was found to be $\mathrm{HCl}$ at $0.02 \mathrm{M}$ concentration, followed by $\mathrm{KCl}$ at $0.04 \mathrm{M}$ and then $\mathrm{NaCl}$ at $0.04 \mathrm{M}$. The worst performing clinoptilolite was the original form under the conditions described in this study and it thus served as a control. The $\mathrm{HCl}$-conditioned clinoptilolite was the most efficient in metal removal $\left(79 \% \mathrm{Co}^{2+}\right.$ and $\left.73 \% \mathrm{Cu}^{2+}\right)$ followed by the $\mathrm{NaCl}$-conditioned form $\left(69 \% \mathrm{Co}^{2+}\right.$ and $\left.54 \% \mathrm{Cu}^{2+}\right)$, while the $\mathrm{KCl}$-conditioned form adsorbed $54 \%$ and $73 \%$ of $\mathrm{Co}^{2+}$ and $\mathrm{Cu}^{2+}$, respectively. The column method was used for the cation-exchange processes with synthetic solutions of $0.0020 \mathrm{M}, 0.0698 \mathrm{M}$ and $0.2000 \mathrm{M}$ of $\mathrm{Co}^{2+}$ and $\mathrm{Cu}^{2+}$ concentrations which were measured using atomic absorption spectroscopy (AAS).
\end{abstract}

Keywords: clinoptilolite, chemical conditioning, ion-exchange, copper and cobalt

\section{Introduction}

There are several factors affecting heavy metal removal from aqueous solutions (Inglezakis and Grigoropoulou, 2004). Particle size, chemical conditioning, contact time, initial metal ion concentration, $\mathrm{pH}$ and the presence of the competing ions in aqueous solutions can be given as some examples of significant factors affecting removal of metals using clinoptilolite (Reed and Arunachalam, 1994).

Natural zeolites which have been chemically conditioned can be used for various industrial applications since chemical conditioning improves their ion exchange performance (Semmens and Seyfarth, 1996) compared to the native clinoptilolite. Such applications include the sequestration of toxic pollutants from industrial effluent and wastes. These natural zeolites are crystals that are naturally occurring hydrated alumino-silicates of alkali and alkaline earth cations. They contain variable $\mathrm{Si} / \mathrm{Al}$ ratios and have exchangeable ions such as $\mathrm{Na}^{+}, \mathrm{K}^{+}$, and $\mathrm{Mg}^{2+}$ in their structures (Culfaz and Yagiz, 2004). The zeolites' framework consists of alumino-silicates with a 3-dimensional structure of $\mathrm{SiO}_{4}$ and $\mathrm{AlO}_{4}$ tetrahedral molecules linked by shared oxygen atoms. Clinoptilolite is one of the most abundant and cosmopolitan natural zeolites, which is widely used because of its ion-exchange properties (Kuronen et al., 2006). Natural zeolites, such as clinoptilolite, are able to lose and gain water in a reversible manner and to exchange their extra framework cations in solution without crystal structural changes (Kuronen et al., 2006).

\footnotetext{
* To whom all correspondence should be addressed.

용 +27(11) 559 6516; fax: +27(11) 5596425 ; e-mail: bmamba@uj.ac.za

Received 20 November 2009; accepted in revised form 31 May 2010
}

The performance of natural zeolites can be improved by performing chemical conditioning on them. This conditioning removes certain cations from zeolites that may hinder ionexchange while exposing the easily exchangeable ones. It has previously been reported in literature that sodium-type natural clinoptilolite favours the exchange of $\mathrm{Cu}^{2+}$ over $\mathrm{Co}^{2+}$ (Zamzow and Murphy, 1992; Coruh, 2008). Cationic exchange of $\mathrm{Cu}$ on chabazite and clinoptilolite, $\mathrm{Zn}$ exchange on clinoptilolite, Co exchange on clinoptilolite and $\mathrm{Cr}$ exchange on phillipsite and chabazite have all been reported (Blanchard et al., 1984; Assenov et al., 1988; Trgo et al., 2006).

Chemical conditioning of a zeolite is a process applied with the aim of replacing certain cations in the zeolite with exchangeable ones (Semmens and Martin, 1988). In this study a natural zeolite, clinoptilolite, was investigated in its original form and was also chemically conditioned using $\mathrm{HCl}$, $\mathrm{NaCl}$ and $\mathrm{KCl}$ (Kesraoui-Ouki et al., 1993; Papachristou et al, 1993; Kesraoui-Ouki et al., 1994), subsequently referred to as $\mathrm{HCl}$-activated, $\mathrm{NaCl}$-activated and $\mathrm{KCl}$-activated throughout this paper. Chemical conditioning also causes exchangeable ions that are already within the zeolite to be more accessible, contributing to the efficient performance of the zeolite. The finally conditioned zeolite should have improved effective ionexchange capability (Bremner and Schultze, 1995; Gradev et al., 1988; Panayotova and Velikov, 2003).

$\mathrm{The}^{+}$ion is the most weakly bound ion in clinoptilolite and thus it can be easily exchanged with the cations in solution. The effect of treatment of clinoptilolite samples was investigated for the removal of $\mathrm{NH}_{4}^{+}$ions from aqueous solution. Cuban clinoptilolite has been previously transformed into its $\mathrm{Na}^{+}, \mathrm{K}^{+}, \mathrm{Ca}^{2+}$ and $\mathrm{Mg}^{2+}$ forms after treatment (Rozic et al., 2002; Zamzow et al., 1990; Milan et al., 1997; Rahmani et al., 2009; Langwaldt, 2008). These studies revealed an improved performance when $\mathrm{Na}^{+}$- clinoptilolite was used. Similarly, 
Inglezakis et al. (1999) determined the effect of batch mode $\mathrm{NaCl}$ treatment on $\mathrm{Pb}^{2+}$ removal by Greek clinoptilolite and found that the effective capacity was increased. The effect of $\mathrm{Na}^{+}$conditioning with different sodium-based chemicals was also examined by several researchers who studied the ability of $\mathrm{Na}^{+}$modified form Bulgarian clinoptilolites, prepared with $\mathrm{NaOH}$ and $\mathrm{NaCl}$, for $\mathrm{Cu}^{2+}$ removal from solution and it was reported that $\mathrm{NaCl}$ treatment resulted in a greater improvement in $\mathrm{Cu}^{2+}$ uptake compared to $\mathrm{NaOH}$ treatment (Panayotova, 2001). The author attributed the difference to the limited ability of $\mathrm{NaOH}$ to displace $\mathrm{K}^{+}, \mathrm{Ca}^{2+}$ and $\mathrm{Mg}^{2+}$.

Among the reported conditioning agents, $\mathrm{HCl}$ is claimed to have a destructive effect on the clinoptilolite structure (Sprynskyy et al., 2005). Kurama and co-workers (2002) treated Bigadic clinoptilolite with $1 \mathrm{M} \mathrm{HCl}$ solution. Hydrochloric acid is reported to cause leaching of $\mathrm{Al}^{3+}$ from zeolites, which compromises the exchange capability of the zeolite (Bailey et al., 1999). Therefore it is important to study the parameters impacting proper zeolite conditioning, especially using $\mathrm{HCl}$. Although $\mathrm{NaCl}$ is the most frequently used conditioning agent in chemical conditioning of zeolites, acid treatment offers advantages for cation exchange, as this study has revealed.

Natural clinoptilolite is abundant in South Africa and is therefore easily accessible which reduces the usually high cost of acquiring this natural mineral. In previous studies it was observed that the use of natural clinoptilolite in its original form was inefficient as a cation-exchanger and it was established that the performance of the zeolite could be improved by chemical conditioning (Mamba et al., 2009; Nyembe et al., 2010). In this study, the exploitation of the ion-exchange potential of Southern African clinoptilolite for the removal of $\mathrm{Cu}^{2+}$ and $\mathrm{Co}^{2+}$ from aqueous synthetic sulphate solutions in batch mode applications was pursued using 3 chemically-conditioned forms of clinoptilolite.

\section{Experimental}

\section{Preparation of synthetic solutions}

The synthetic solutions were prepared as described in Mamba et al. (2009). For AAS analyses respective solutions of copper and cobalt were prepared by dissolving $\mathrm{CoSO}_{4} \cdot 7 \mathrm{H}_{2} \mathrm{O}$ (analytical grade) and $\mathrm{CuSO}_{4} .5 \mathrm{H}_{2} \mathrm{O}$ (analytical grade) in deionised water. The effect of the presence of one cation on the other's removal efficiency was studied by varying the metal ion concentration in solution. Studies on the $\mathrm{Co} / \mathrm{Cu}$ mixed synthetic solutions were based on solutions of copper and cobalt prepared at stoichiometric ratios of $\mathrm{Co}: \mathrm{Cu}$ of 1:1, 1:5, 1:9, 5:1 and 9:1, which corresponded to the following concentration ratios of $\mathrm{Co:Cu}-0.0020: 0.0020 \mathrm{~g} / \ell, 0.0020: 0.0698 \mathrm{~g} / \ell, 0.0020: 0.2000$ $\mathrm{g} / \ell, 0.0698: 0.0020 \mathrm{~g} / \ell$ and 0.2000:0.0020 $\mathrm{g} / \ell$, respectively. These concentrations were arbitrarily chosen with the intention of generating weakly-, moderately- and highly-concentrated solutions. The aqueous synthetic solutions were stored at room temperature (approx. $25^{\circ} \mathrm{C}$ ). The samples were utilised within $48 \mathrm{~h}$ after preparation to minimise errors from precipitation and container-plating of the metal ions.

\section{Preparation of clinoptilolite}

In addition to original forms, conditioned forms of Southern African clinoptilolite were also used in this study. Conditioning of the samples was aimed at enhancing the ion exchange capacity of the material by replacing exchangeable cations on clinoptilolite structure with a single cation. Sodium chloride, potassium chloride and hydrochloric acid $(\mathrm{NaCl}, \mathrm{KCl}$ and $\mathrm{HCl}$ ) were selected as the conditioning agents since $\mathrm{K}^{+}$, $\mathrm{H}^{+}$and $\mathrm{Na}^{+}$ions are weakly bound ions on clinoptilolite, and thus once the clinoptilolite is converted to the homoionic form they can easily exchange with heavy metal cations (Inglezakis and Grigoropoulou, 2004). For this purpose, original clinoptilolite was conditioned and 2 different conditioned samples were prepared for each chemical reagent. The raw zeolite was crushed with jaw crushers and sieved through screens to a size range of 2.8 to $5.6 \mathrm{~mm}$. A fraction of this average particle size was rinsed with distilled water and air-dried for $24 \mathrm{~h}$. Chemical conditioning of clinoptilolite was performed using $\mathrm{HCl}, \mathrm{KCl}$ and $\mathrm{NaCl}$ solutions at concentrations of 0.02 and $0.04 \mathrm{M}$, based on the findings of the authors' earlier work (Mamba et al., 2009). Fractions of clinoptilolite were soaked in the respective solutions for $8 \mathrm{~h}$, rinsed 3 times in deionised water of $\mathrm{pH} 6.7$ and dried in an oven at $50^{\circ} \mathrm{C}$ for $24 \mathrm{~h}$. Selection of the conditions used in the preparation of the clinoptilolite was based on preliminary experiments performed with $\mathrm{HCl}$ in the laboratory.

\section{Scanning electron microscopy (SEM)}

A scanning electron microscope (SEM) is used to study the surfaces of solids to give information about their morphology and topological presentations. Such presentations may provide possible explanations about the solid's behaviour. To study the morphology and topological patterns of the original HClactivated, $\mathrm{NaCl}$-activated and $\mathrm{KCl}$-activated clinoptilolite, a SEM JEOL JSM-840 instrument was used. Grains of 2.8 to $5.6 \mathrm{~mm}$ size range were mounted on aluminium stubs with carbon tape on a graphite support unit. They were then coated with gold to improve visibility and also to make the surface conductive so as to prevent charging effects. The samples were then subjected to an electron beam under vacuum to obtain micrographs of the zeolites.

\section{Adsorption experiments}

The ion-exchange processes of $\mathrm{Co}^{2+}$ and $\mathrm{Cu}^{2+}$ on the clinoptilolite were performed at room temperature. Glass columns of $20 \mathrm{~mm}$ diameter and $300 \mathrm{~mm}$ of length were pre-loaded with $25 \mathrm{~g}$ of either original clinoptilolite or activated clinoptilolite and a volume of $25 \mathrm{~m} \ell$ of the prepared $\mathrm{Co}^{2+}$ and $\mathrm{Cu}^{2+}$ bearing solutions was passed through each form of zeolite (Kocasoy and Sahin, 2007). The contact time afforded for the experiments was $60 \mathrm{~min}$. The effluent solutions were collected at $5,10,15,30,45$ and 60 min intervals and analysed for final metal content using AAS. Figure 1 shows the experimental set-up used for the ion-exchange experiments.

\section{Fourier Transform Infra Red (FTIR) spectroscopy characterisation}

The FTIR technique was used to determine the functionalities present in the $\mathrm{HCl}$-activated, $\mathrm{NaCl}$-activated, $\mathrm{KCl}$-activated and original forms of clinoptilolite, as reported in Mamba et al. (2009). This characterisation was done in order to ascertain whether chemical conditioning of original clinoptilolite exposes other latent functional groups. This would assist in offering interpretation pertaining to the ion-exchange capabilities of the clinoptilolite. Dry pellets were prepared by mixing finely milled clinoptilolite (approx. $75 \mu \mathrm{m}$ ) with a bromide binder in a ratio of 1:10 of sample to binder $(0.05 \mathrm{~g}$ 


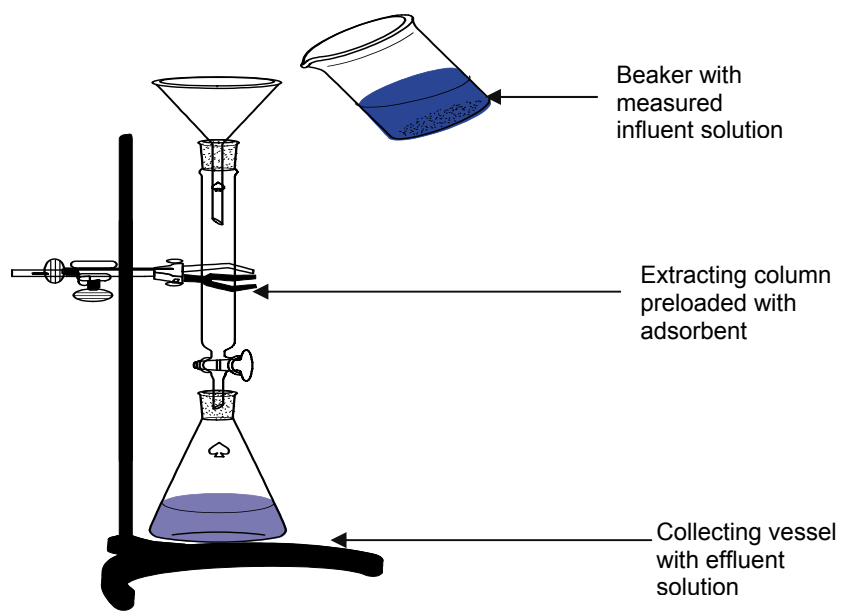

Figure 1

lon-exchange apparatus used in the ion-exchange experiments

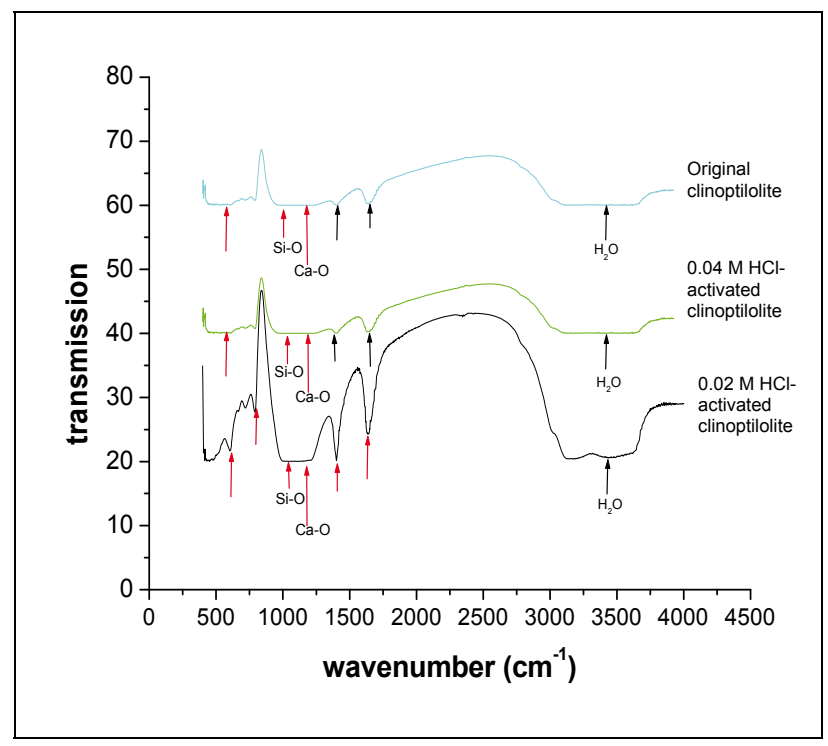

Figure 2

The FTIR spectra for original and $\mathrm{HCl}$-activated clinoptilolite forms at concentrations of $0.02 \mathrm{M}$ and $0.04 \mathrm{M}$ (from Mamba et al., 2009)

clinoptilolite: $0.5 \mathrm{~g}$ binder); mixing was done using a pestle and mortar until homogeneity of the mixture was achieved. The IR data and IR spectra were obtained for the different pellets after running samples using the Midac FTIR 5000 spectrophotometer on $\mathrm{CaF}_{2}$ plates with the various bands recorded in wavenumbers $\left(\mathrm{cm}^{-1}\right)$.

\section{Results and discussion}

\section{Fourier Transform Infra Red analyses}

The IR-spectra for original and $\mathrm{HCl}$-activated clinoptilolite are shown in Fig. 2.

At the range of 4000 to $3000 \mathrm{~cm}^{-1}$ the original and $0.04 \mathrm{M}$ $\mathrm{HCl}$-activated forms of clinoptilolite showed distinct stretching, which is typical of water absorption (Majedova, 2003). A small peak was observed for $0.02 \mathrm{M}$ at this range. This shows that water adsorption and retention by clinoptilolite is increased by $\mathrm{HCl}$ activation at $0.02 \mathrm{M}$ concentration. At the 1750 to

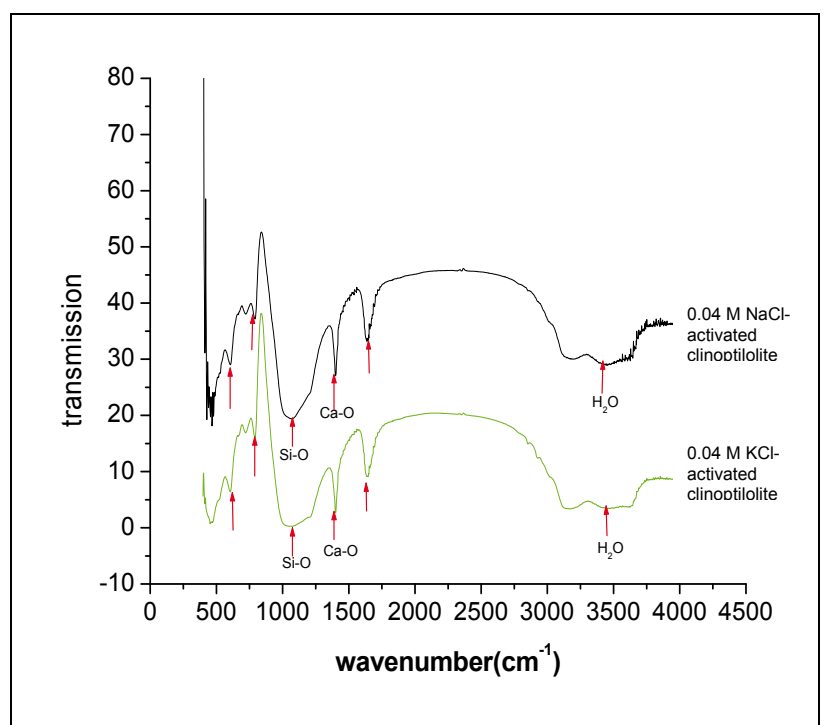

Figure 3

FTIR spectra for $\mathrm{KCl}$ - and $\mathrm{NaCl}$-activated clinoptilolite both activated at $0.04 \mathrm{M}$

$1500 \mathrm{~cm}^{-1}$ range, the $0.02 \mathrm{M} \mathrm{HCl}$-activated clinoptilolite showed distinct peaks and again the original and the $0.04 \mathrm{M}$ activated forms showed a small peak. This could be as a result of $0.02 \mathrm{M}$ activation washing out the non-zeolitic impurities present in the original clinoptilolite, as confirmed by SEM. The small peaks at about 1250 with the $0.04 \mathrm{M}$ and $0.02 \mathrm{M} \mathrm{HCl}$ activated form could be due to the strength of the acid which resulted in the leaching out of calcium. At this very wavelength, the original form of clinoptilolite showed a stretched band which is due to $\mathrm{Ca}-\mathrm{O}$. There were peaks observed for all the clinoptilolite forms at $1558 \mathrm{~cm}^{-1}$ which may be due to the bending vibrations of adsorbed water. This is expected since, given its porous structure, desiccation of the zeolite at high temperatures $\left(50^{\circ} \mathrm{C}\right)$ will increase its hydrophilic (water absorption) properties ( $\mathrm{Ng}$ and Mintova, 2008).

The stretching between 1500 and $1000 \mathrm{~cm}^{-1}$ observed in Fig. 2 indicates the presence of a high content of calcite in the sample as confirmed by SEM. The strong band at $1341 \mathrm{~cm}^{-1}$ (due to Si-O stretching) is the main characteristic band for quartz (Al-Degs et al., 2003). The peaks observed between 1000 and $600 \mathrm{~cm}^{-1}$ are present in all the forms of clinoptilolite; one characteristic band appears at $836 \mathrm{~cm}^{-1}$ for all the forms. This is the quartz band. Quartz is common with zeolites, especially those of the Heulandite family. The peak that appears at $753 \mathrm{~cm}^{-1}$ for the original clinoptilolite form appears at $759 \mathrm{~cm}^{-1}$ for the activated zeolite. There is a peak that appears at $686 \mathrm{~cm}^{-1}$ for the original form while for the acid-activated forms it appears at $635 \mathrm{~cm}^{-1}$. This shift could be attributed to the action of the acid.

In essence, the characteristic IR bands of the $\mathrm{KCl}$ - and $\mathrm{NaCl}$-activated clinoptilolite forms were comparable to the $\mathrm{HCl}$-activated forms. The differences were only in intensity and the slight apparent shifts in the positions of the peaks. These shifts were less pronounced in the $\mathrm{KCl}$ - and $\mathrm{NaCl}-$ activated clinoptilolite forms than in the $\mathrm{HCl}$-activated forms as shown in Fig. 3.

There were peaks between 2000 and $1250 \mathrm{~cm}^{-1}$ which indicated the presence of a high content of calcite in the sample. The strong band at $850 \mathrm{~cm}^{-1}$ is the main characteristic band 


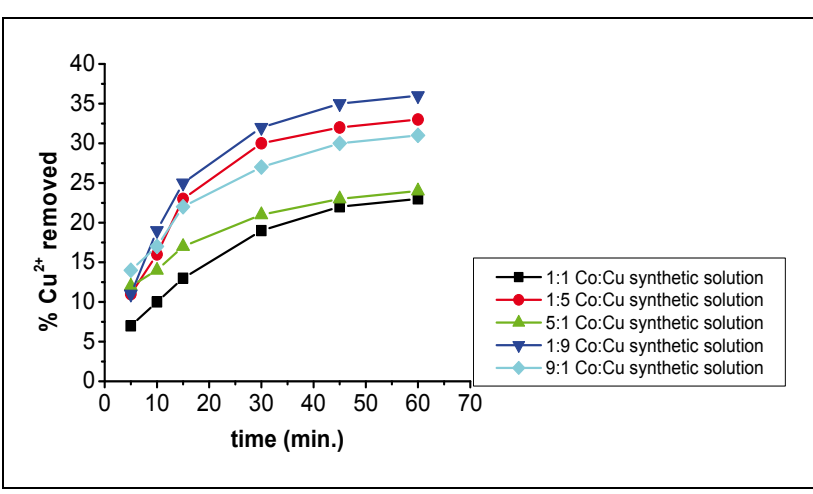

Figure 4

$\mathrm{Cu}^{2+}$ removal from $\mathrm{Co} / \mathrm{Cu}$ mixed synthetic solutions of different Co:Cu concentrations using original clinoptilolite

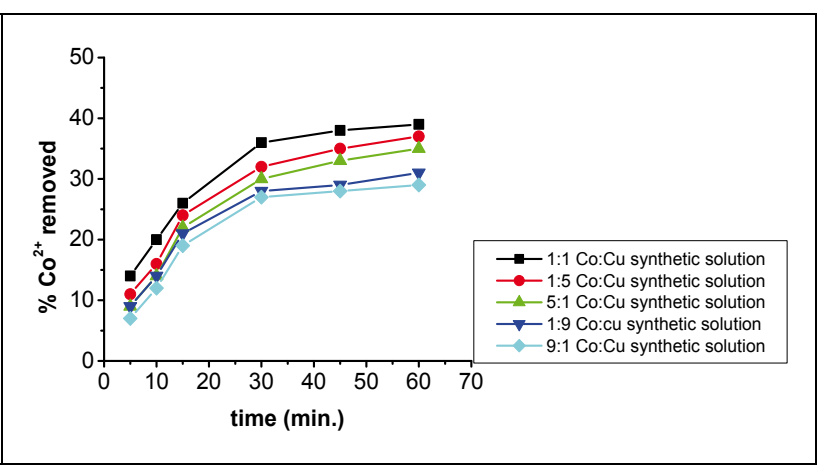

Figure 5

$\mathrm{Co}^{2+}$ removal from $\mathrm{Co} / \mathrm{Cu}$ mixed synthetic solutions of different Co:Cu concentrations using original clinoptilolite

for quartz (Al-Degs et al., 2003). Other small characteristic quartz bands appear between 850 and $500 \mathrm{~cm}^{-1}$. The positions of the peaks appear to have shifted when compared to the $\mathrm{HCl}$ activated forms. This could be attributed to the mild action of the $\mathrm{KCl}$ and $\mathrm{NaCl}$. The $0.04 \mathrm{M} \mathrm{KCl}$-activated and $\mathrm{NaCl}$-activated clinoptilolites' FTIR spectra were identical to their $0.02 \mathrm{M}$ activated counterparts. We have therefore only represented the spectra of the $0.04 \mathrm{M}$ activated forms of clinoptilolite for both $\mathrm{KCl}$ and $\mathrm{NaCl}$ conditioning. It can be deduced that the 2 concentrations used did not markedly alter the zeolite's structure.

\section{Copper and cobalt removal using original clinoptilolite}

Figures 4 and 5 show that the 1:1 $\mathrm{Co:Cu}$ ratio showed the lowes removal of $\mathrm{Cu}^{2+}$ and the highest removal of $\mathrm{Co}^{2+}$. This is likely to have been due to the fact that the $\mathrm{Cu}^{2+}$ formed more bulky and stable complexes with the water molecules in the solution (Fernandez et al., 1994).

The bulky complex-formation by $\mathrm{Cu}^{2+}$ ions resulted in the availability of $\mathrm{Co}^{2+}$ ions for sorption. The highest $\mathrm{Cu}^{2+}$ removal recorded for this form of clinoptilolite (non-activated) was 35\% and was recorded with a 1:9 Co:Cu ratio. The lowest removal efficiency for $\mathrm{Cu}^{2+}$ was at $23 \%$ with the $1: 1 \mathrm{Co}$ :Cu ratio. On the other hand, the highest removal efficiency recorded for $\mathrm{Co}^{2+}$ ions was $40 \%$ and was obtained with the $1: 1 \mathrm{Co}: \mathrm{Cu}$ solution as shown in Fig. 5.

This was as expected since this solution recorded the lowest removal efficiency for $\mathrm{Cu}^{2+}$ ions. The lowest removal efficiency recorded for $\mathrm{Co}^{2+}$ was $26 \%$ and was recorded with the 9:1

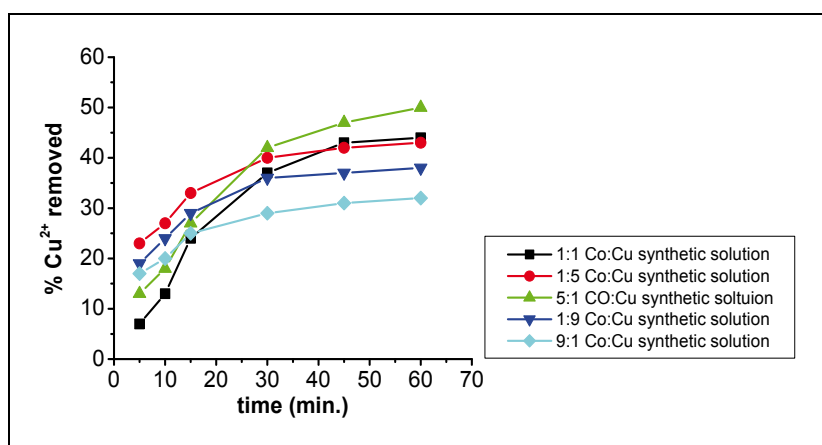

Figure 6

$\mathrm{Cu} 2+$ removal from $\mathrm{Co} / \mathrm{Cu}$ mixed synthetic solutions of different $\mathrm{Co}: \mathrm{Cu}$ concentrations using $\mathrm{NaCl}$-activated clinoptilolite

$\mathrm{Co}: \mathrm{Cu}$ synthetic solution where the $\mathrm{Co}^{2+}$ ion concentration was the highest. Another solution where $\mathrm{Co}^{2+}$ concentration was higher than that of $\mathrm{Cu}^{2+}(5: 1)$ also recorded only $31 \%$ removal. It is evident that the higher the $\mathrm{Co}^{2+}$ ion concentration in solution, the higher the removal efficiency for $\mathrm{Co}^{2+}$ ions; the converse was also true.

The low metal removal efficiencies could be due to the original clinoptilolite's heterogeneous structure since there was no modification applied to it. It is also possible that the clinoptilolite surface and pore openings were partially covered by dust produced during crushing of the clinoptilolite, resulting in pore clogging which led to smaller ion-exchange capacity and slower ion-exchange rates (Inglezakis et al., 1999). Pore clogging by fine particles, which can be reduced by chemical conditioning of the zeolite, has also been reported as a possible cause of smaller ion exchange capacity and slower exchange rates (Mondale et al., 1995). According to one study, pore clogging can affect the ion-exchange capacity by up to $15 \%$ (Carland and Aplan, 1995). This could result in the locations of exchangeable ions not being evenly distributed within the zeolite, such that there would be delays in the ion exchange process due to exchangeable ions competing with other ions not involved in the ion-exchange process.

\section{Copper and cobalt removal using $\mathrm{NaCl}$-activated clinoptilolite}

Figure 6 depicts $\mathrm{Cu}^{2+}$ removal with $\mathrm{NaCl}$-activated clinoptilolite.

In synthetic solutions where there were more $\mathrm{Cu}^{2+}$ ions than $\mathrm{Co}^{2+}$ ions (1:5 and 1:9) the graphs displayed similar removal patterns. The removal efficiency started off at a higher rate and then slowed down almost abruptly before reaching a plateau. This must have been due to the nature of the zeolite's surface, i.e. surface charge which determines the ion-exchange mechanism in the uploading of $\mathrm{Cu}^{2+}$ onto the zeolite. It is possible that there were $\mathrm{Cu}^{2+}$ affinitive sites immediately available on the zeolite's surface, such that the uploading started off very fast; these $\mathrm{Cu}^{2+}$ affinitive sites then became depleted with time as the $\mathrm{Cu}^{2+}$ adopted another uploading mechanism that proved to be slower than ion-exchange (Ederm et al., 2004).

The most likely mechanism to have occurred at first is the ion-exchange mechanism which is known to be quick (Ederm et al., 2004; Zachara et al., 1991; McBride, 1980). It is suggested that the latter part of the metal ion loading takes place inside the zeolite and is slow due to the percolation of the solution through the clinoptilolite channels. In light of the 


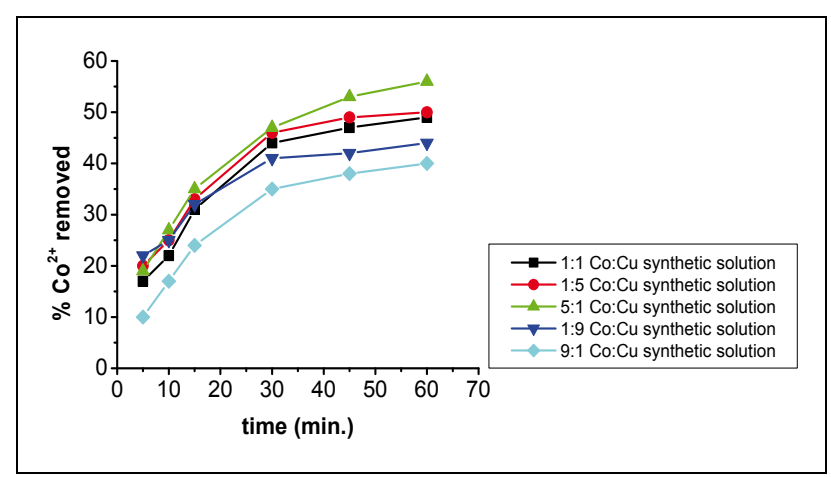

Figure 7

$\mathrm{Co}^{2+}$ removal from $\mathrm{Co} / \mathrm{Cu}$ mixed synthetic solutions of different $\mathrm{Co}: \mathrm{Cu}$ concentrations using $\mathrm{NaCl}$-activated clinoptilolite

fact that there was more $\mathrm{Cu}^{2+}$ than $\mathrm{Co}^{2+}$ in solution there were more free and available $\mathrm{Cu}^{2+}$ ions in solution for exchange, such that the $\mathrm{Cu}^{2+}$ ions were uploaded first. As time went by the $\mathrm{Cu}^{2+}$ ions that had formed $\mathrm{Co}-\mathrm{Cu}$ non-stable complexes in a dynamic fashion were later uploaded as they broke away from their $\mathrm{Co}^{2+}$ ion counterparts in a manner allowed by their complex formation dynamics. The removal patterns in the 5:1 and 1:1 Co:Cu aqueous solutions showed similar trends. Initially, there were low removal efficiencies which gradually picked up before reaching a plateau. It is possible in this case that both ion exchange and precipitation mechanisms happened simultaneously.

In the 5:1 $\mathrm{Co}: \mathrm{Cu}$ aqueous solution shown in Fig. 7 there were more $\mathrm{Co}^{2+}$ ions than $\mathrm{Cu}^{2+}$ ions. This meant that most of the $\mathrm{Cu}^{2+}$ ions participated in the formation of $\mathrm{Co}-\mathrm{Cu}$ non-stable complexes in solution such that the $\mathrm{Cu}^{2+}$ ions were not immediately available for uploading via ion-exchange mechanisms. Thus, the $\mathrm{Cu}^{2+}$ ions were uploaded as they broke away from the non-stable complexes as allowed by the chemical bonding dynamics. In the 1:1 Co:Cu solution that there were equal amounts of $\mathrm{Cu}^{2+}$ ions available to $\mathrm{Co}^{2+}$ ions for the formation of non-stable complexes. This results in the non-immediate availability of $\mathrm{Cu}^{2+}$ ions for uploading, causing the ion-exchange process to be slowed down. On the whole, the removal efficiency for both $\mathrm{Cu}^{2+}$ and $\mathrm{Co}^{2+}$ was highest with the 5:1 $\mathrm{Co}: \mathrm{Cu}$ aqueous solutions and the lowest efficiencies were recorded with the 9:1 Co:Cu aqueous solutions. What was expected was that the ratio of removal that showed the highest removal for $\mathrm{Co}^{2+}$ would show the least removal for $\mathrm{Cu}^{2+}$ and vice versa. The highest removal efficiencies recorded for $\mathrm{NaCl}$-activated clinoptilolite were $56 \%$ for $\mathrm{Co}^{2+}$ and $47 \%$ for $\mathrm{Cu}^{2+}$. The lowest efficiencies were $31 \%$ and $40 \%$ for $\mathrm{Cu}^{2+}$ and $\mathrm{Co}^{2+}$, respectively. These results were obtained with the $0.04 \mathrm{M} \mathrm{NaCl}$-activated form of clinoptilolite.

\section{Copper and cobalt removal using $\mathrm{KCl}$-activated clinoptilolite}

The highest percentage removal recorded for $\mathrm{Cu}^{2+}$ ion was $50 \%$ which was obtained with 5:1 Co:Cu solution (Fig. 8)

The 9:1 Co:Cu solution was expected to record a high percentage removal since it also contained a high concentration of $\mathrm{Co}^{2+}$ ions, however it recorded the lowest (38\%). This discrepancy can be attributed to the non-homogeneous nature of the clinoptilolite. The 1:1, 1:5 and 1:9 $\mathrm{Co}: \mathrm{Cu}$ solutions behaved in such a manner that the fewer $\mathrm{Cu}^{2+}$ ions that were present in the

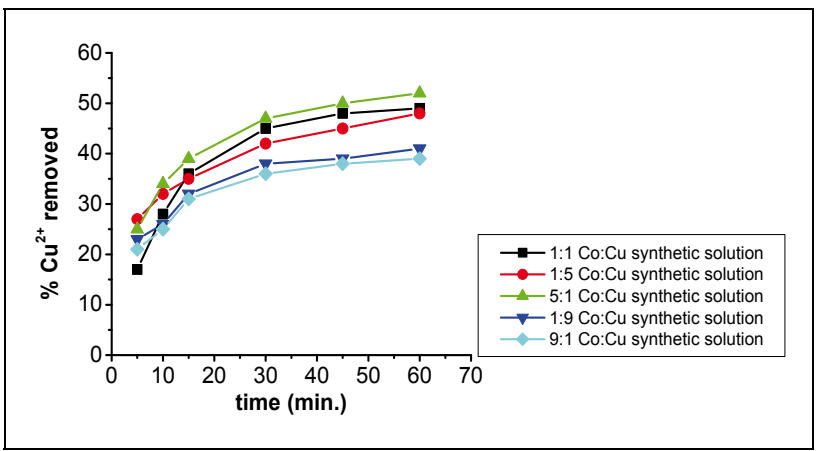

Figure 8

$\mathrm{Cu}^{2+}$ removal from Co/Cu mixed synthetic solutions of different $\mathrm{Co}: \mathrm{Cu}$ concentrations using $\mathrm{KCl}$-activated clinoptilolite

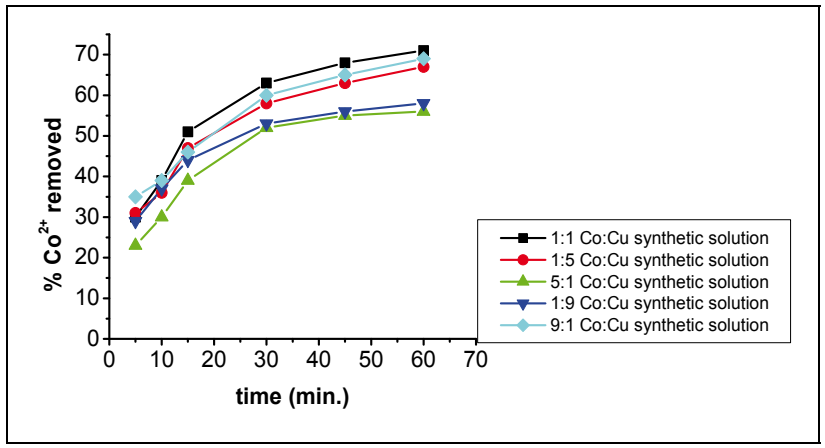

Figure 9

$\mathrm{Co}^{2+}$ removal from Co/Cu mixed synthetic solutions of different $\mathrm{Co}: \mathrm{Cu}$ concentrations using $\mathrm{KCl}$-activated clinoptilolite

solutions the more efficiently the $\mathrm{Cu}^{2+}$ was adsorbed (48\%, $47 \%$ and $42 \%$, respectively).

The 1:1, 9:1 and 1:5 Co:Cu solutions recorded 70\%, $68 \%$ and $66 \%$, respectively (Fig. 9). The 5:1 and 1:9 Co:Cu solutions recorded $52 \%$ and $55 \%$, respectively. It should be noted that when there was a high concentration of $\mathrm{Cu}^{2+}$ ions in the solution, $\mathrm{Co}^{2+}$ removal was limited. The optimal ratio resulting in the most efficient removal was 1:1 $\mathrm{Co}: \mathrm{Cu}$ in solution.

On the whole, the $\mathrm{KCl}$-activated clinoptilolite showed the best performance over the original and $\mathrm{NaCl}$-activated forms.

\section{Copper and cobalt removal using $\mathrm{HCl}$-activated clinoptilolite}

It has been documented that acid treatment of natural clinoptilolite improves its adsorbent properties (Kuronen et al., 2006; Inglezakis and Grigoropoulou, 2004). This is due to de-catination, de-alumination and the dissolution of amorphous silica fragments blocking the channels. A study by Korkuna and coworkers also revealed that there is a change in the clinoptilolite structure after acid treatment with dilute acid activations accounting for improved removal capability of the HCl-clinoptilolite (Korkuna et al., 2006). Studies by Vasylechko and co-workers confirm the findings of this study with respect to the effect of acid-activation of natural clinoptilolite (Vasylechko et al., 1999; Vasylechko et al., 2000). From the kinetics graphs in Figs. 10 and 11 it was observed that a ratio of $\mathrm{Co}: \mathrm{Cu}$ 1:1 favours removal efficiency for $\mathrm{Co}^{2+}$ more than it favours $\mathrm{Cu}^{2+}$ removal.

It is suggested that in this solution ( $\mathrm{Co:} \mathrm{Cu} 1: 1)$ some of 


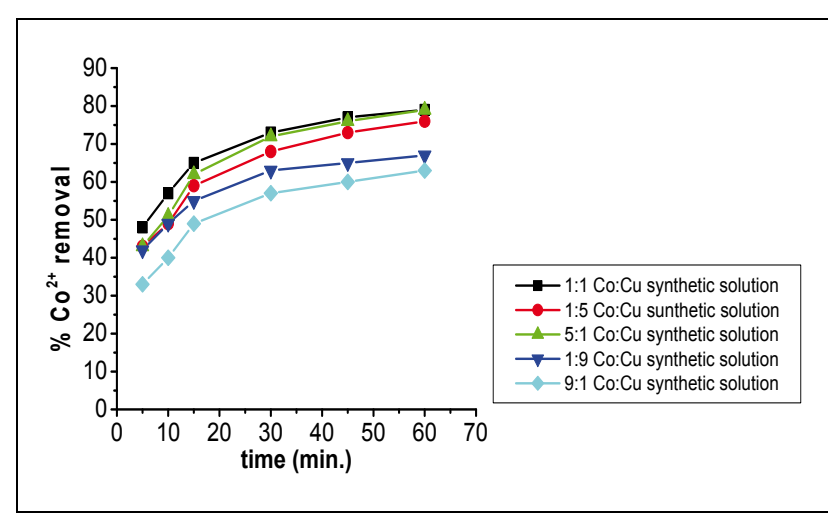

Figure 10

$\mathrm{Co}^{2+}$ removal from $\mathrm{Co} / \mathrm{Cu}$ synthetic solutions of different $\mathrm{Co}: \mathrm{Cu}$ concentrations using $\mathrm{HCl}$-activated clinoptilolite

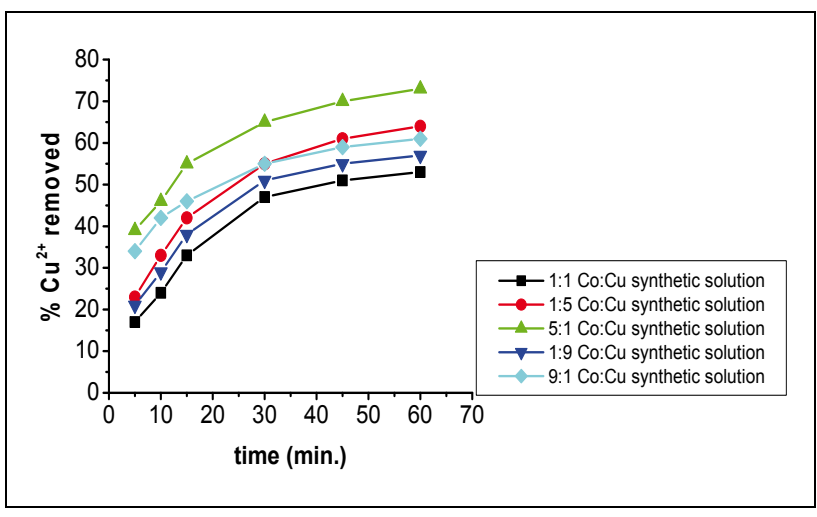

Figure 11

$\mathrm{Cu}^{2+}$ removal from $\mathrm{Co} / \mathrm{Cu}$ mixed synthetic solutions of different $\mathrm{Co}: \mathrm{Cu}$ concentrations using $\mathrm{HCl}$-activated clinoptilolite

the $\mathrm{Cu}^{2+}$ ions form stable hydrated complexes with water and some of the $\mathrm{Co}^{2+}$ ions in the solutions form complexes which are too bulky to move into the zeolite pores. In the 1:5 Co: $\mathrm{Cu}$ solution, removal of $\mathrm{Cu}^{2+}$ ions is very high (73\%). This could be as a result of there now being more 'free' available $\mathrm{Cu}^{2+}$ ions than in the 1:1 $\mathrm{Co}: \mathrm{Cu}$ solution. However, a sudden change was observed for the 1:9 and 9:1 Co:Cu solutions. It was expected that the removal of $\mathrm{Cu}^{2+}$ would be more feasible if more of the $\mathrm{Cu}^{2+}$ ions were present in the matrix.

It apparently became difficult for the $\mathrm{Cu}^{2+}$ to upload, in comparison to the uploading of $\mathrm{Co}^{2+}$ ions $(79 \%$ in the $1: 1 \mathrm{Co}: \mathrm{Cu}$ solution), as shown in Fig. 11. This might be due to cationcation interactions of $\mathrm{Co}-\mathrm{Cu}$ which could have resulted in the formation of stable complexes thus lowering metal uptake rates.

It is possible that an increase of $\mathrm{Cu}^{2+}$ ions in the solution is favoured only to a certain limited extent with respect to $\mathrm{Cu}^{2+}$ ions uptake. The ion-exchange in this case was expected to be faster than was apparent in the first $10 \mathrm{~min}$, since the number of active sites in the zeolite were the same as those provided for the single-cation solutions. However there seemed to be a "struggle" in the quest to occupy the active sites. This could again be attributed to cation-cation interactions as well as to the water of hydration in the solutions and the non-homogeneous nature of the clinoptilolite. These active sites eventually become saturated with metal ions and unable to further accommodate more ions at higher concentrations.

The selectivity of $\mathrm{Co}^{2+}$ over $\mathrm{Cu}^{2+}$ in these solutions can be

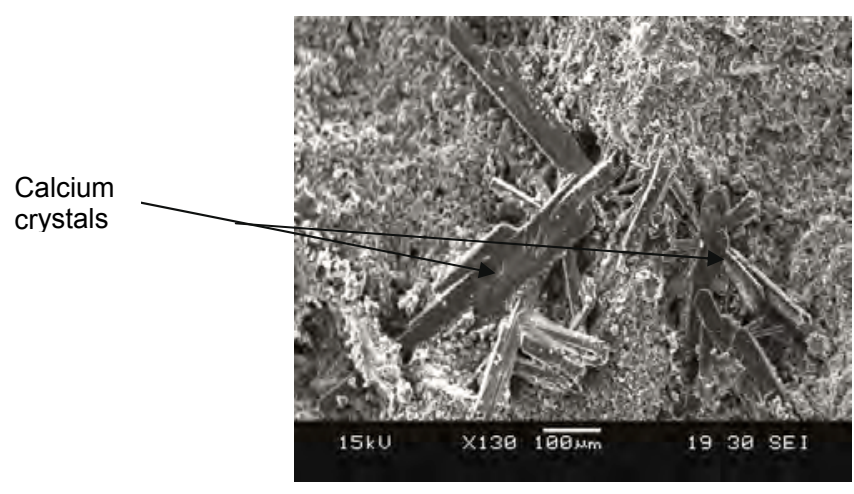

Figure 12

SEM image showing calcium on the original clinoptilolite's surface

explained in the following manner: For larger anhydrite ions, the charge is more dispersed and the water of hydration is held less strongly by the metal cation. This leads to a situation where the larger the ion, the less hydrated it is and the smaller the relative size of the hydrated ion. For example, anhydrous $\mathrm{Cu}^{2+}$ is larger than the anhydrous $\mathrm{Co}^{2+}$ ion, but hydrated $\mathrm{Cu}^{2+}$ ion is smaller than the hydrated $\mathrm{Co}^{2+}$. The $\mathrm{Cu}^{2+}$ ion has a valence of +2 and can hold its hydration shell very strongly, while the $\mathrm{Co}^{2+}$ ion, a larger divalent cation, holds its hydration shell relatively less strongly. As a result, the $\mathrm{Co}^{2+}$ ion can lose its hydration shell readily when it is approaching the clinoptilolite surface and establish a stronger bond with the clinoptilolite than $\mathrm{Cu}^{2+}$, whose approach in the proximity of the clinoptilolite surface is prevented by the bulky surrounding water molecules.

On the whole, the low removal efficiencies exhibited by original clinoptilolite provide evidence that the clinoptilolite surface and pore openings are partially covered by dust, resulting in pore clogging which may lead to smaller ionexchange capacity and slower ion-exchange rates of the cations (Athanasiadis and Helmreich, 2005). The Na-activated clinoptilolite form did not show any marked improvement or decline in metal removal efficiency when the activating concentration was increased to $0.04 \mathrm{M}$. The Na-activated clinoptilolite form exhibited fair metal removal efficiency. $\mathrm{HCl}$-activation of the clinoptilolite samples was found to improve their effective sorption capacity with the $0.02 \mathrm{M} \mathrm{HCl}$ concentration. $\mathrm{HCl}$-activation of the clinoptilolite samples was found to improve the effective sorption capacity with the $0.02 \mathrm{M} \mathrm{HCl}$ concentration.

\section{Scanning electron microscopy analyses}

The SEM analysis was performed in order to determine the morphological changes brought about by the conditioning chemicals. The original clinoptilolite was observed to have crystalline calcium on its surface as shown in Fig. 12.

It is on these sites that most of the ion-exchange and adsorption takes place, in the case of original clinoptilolite. The abundance of the calcium must have limited metal upload in the inner parts of the clinoptilolite since the highest recorded result for cation removal using this form of clinoptilolite was $40 \%$ for $\mathrm{Co}$ and $35 \%$ for $\mathrm{Cu}$.

The SEM images in Fig. 13a show a more open structure of the HCl-activated clinoptilolite's surface compared to the inactivated zeolite shown in Fig. $13 \mathrm{~b}$.

This explains why the acid-activated clinoptilolite 
Figure 13a

SEM image of original clinoptilolite at $x$

2 000magnification showing

the 'rough and closed'

appearance of original

clinoptilolite (Mamba et al., 2009)

Figure 13b

SEM image of $\mathrm{HCl}$ activated

clinoptilolite at $x 2000$

magnification showing a

somehow 'open and softer' appearance (Mamba et al., 2009)
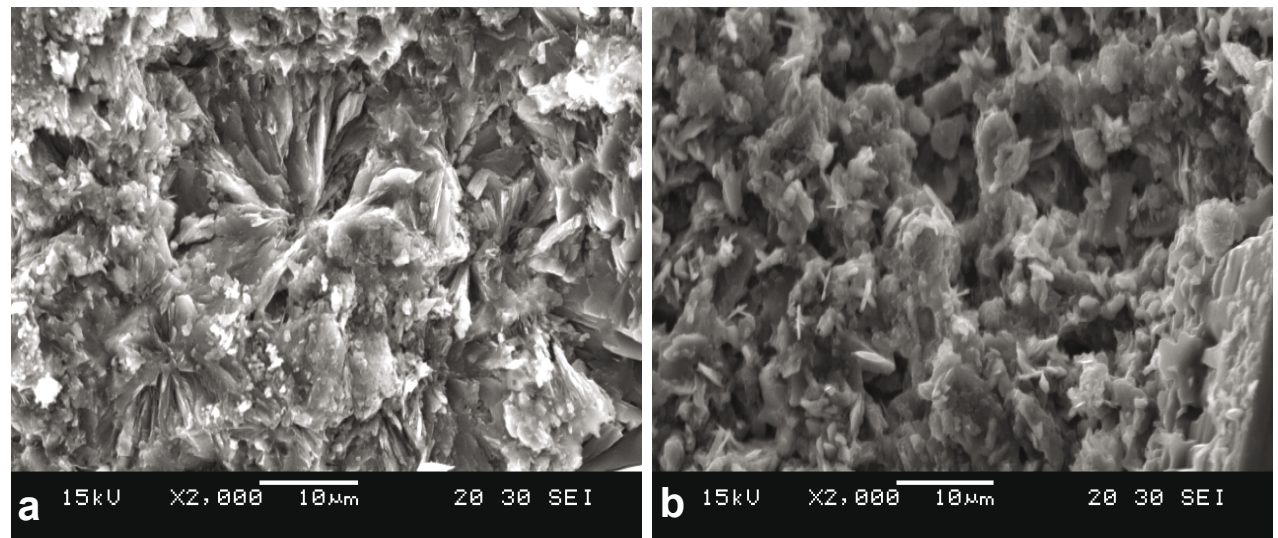

Calcium

crystals

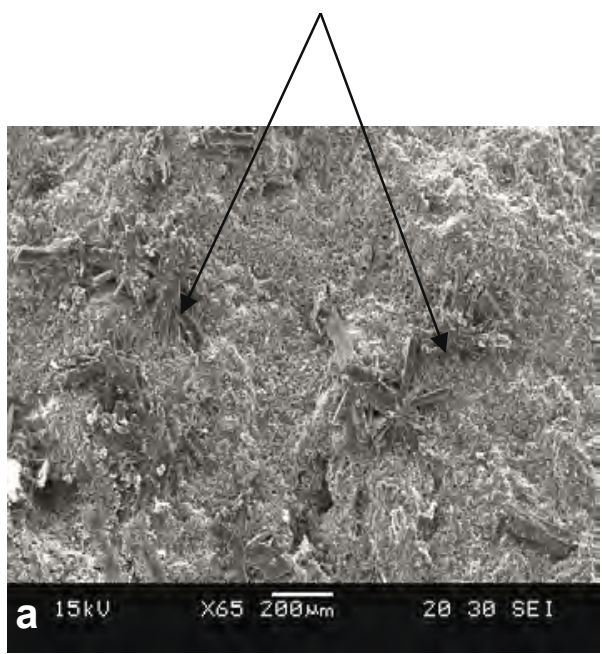

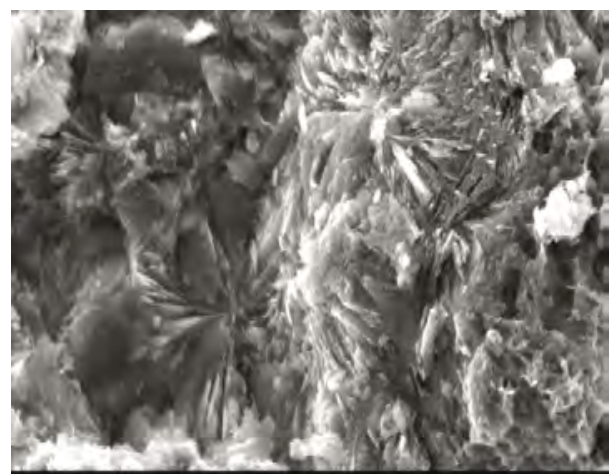

b $15 \mathrm{kU} \quad \mathrm{x}, 200 \overline{10 \mathrm{~mm}}$

2030 SEI performed better than all of the other forms of clinoptilolite. There were some morphological changes where the clinoptilolite was observed to exhibit a more open and somewhat softened structure brought about by $\mathrm{HCl}$-activation, when comparing the 2 SEM images (Misaelides et al., 1995). Such was not the case with the clinoptilolite forms conditioned with $\mathrm{NaCl}$ and $\mathrm{KCl}$. It is this modification that is thought to be responsible for the ease of cation removal observed with the $\mathrm{HCl}$-activated clinoptilolite. It was observed that conditioning with $\mathrm{NaCl}$ and and $\mathrm{KCl}$ did not alter the morphology of the clinoptilolite, as shown in Figs. 14a and 14b.

The retention of structural integrity of the clinoptilolite is due to the non-corrosive nature of the 2 chemicals $(\mathrm{NaCl}$ and $\mathrm{KCl}$ ) compared to $\mathrm{HCl}$. The corrosive nature of $\mathrm{HCl}$ is able to eliminate the particles that clog the pores of the zeolite thus improving its adsorption and ion-exchange properties.

\section{Conclusions}

The HCl-conditioned clinoptilolite was the most efficient form in the removal $\left(79 \% \mathrm{Co}^{2+}\right.$ and $\left.73 \% \mathrm{Cu}^{2+}\right)$ followed by the $\mathrm{NaCl}$-conditioned form $\left(69 \% \mathrm{Co}^{2+}\right.$ and $\left.54 \% \mathrm{Cu}^{2+}\right)$ while the $\mathrm{KCl}$-conditioned form adsorbed $54 \%$ and $73 \%$ of $\mathrm{Co}^{2+}$ and $\mathrm{Cu}^{2+}$, respectively. The results obtained with the $\mathrm{HCl}$-activated and $\mathrm{KCl}$-activated clinoptilolite using synthetic $\mathrm{Co} / \mathrm{Cu}$ solutions show that chemically activated Southern African clinoptilolite can be used effectively for the removal of metal cations from aqueous solutions, especially leached solutions obtained during mineral processing.

\section{Acknowledgements}

Funding obtained from the National Research Foundation (NRF), Mintek/DST, Nanotechnology Innovation Centre (NIC) and the University of Johannesburg is gratefully appreciated.

\section{References}

AL-DEGS Y, TUTUNJI M and BAKER H (2003) Isothermal and kinetic adsorption behaviour of $\mathrm{Pb}^{2+}$ ions on natural silicate minerals. Clay Miner. 38 501-509.

ASSENOV A, VASSILEV C and KOSTOVA M (1988) Simultaneous sorption of metal ions on natural zeolite clinoptilolite. In: Kallo D and Sherry HS (eds.) Occurrence, Properties and Utilization of Natural Zeolites. Akadémiai Kiado, Budapest. 471-480.

ATHANASIADIS K and HELMREICH B (2005) Influence of chemical conditioning on the ion exchange capacity and on kinetics of zinc uptake by clinoptilolite. Water Res. 39 1527-1532.

BAILEY SE, OLIN T J, BRICKA RM and ADRIAN DD (1999) A review of potentially low cost sorbents for heavy metals. Water Res. 33 2469-2479.

BLANCHARD G, MAUNAYE M and MARTIN G (1984) Removal of heavy metals from water by means of natural zeolites. Water Res. 18 1501-1507.

BREMNER PR and SCHULTZE LE (1995) Ability of 
clinoptilolite-rich tuffs to remove metal cations commonly found in acidic drainage. In: Ming DW and Mumpton FA (eds.) Natural Zeolites '93: Occurrence, Properties, Use. International Committee on Natural Zeolites, Brockport, New York. 397-403.

CORUH S (2008) Treatment of copper industry waste and production of sintered glass-ceramic. Waste Manage. Res. 24 234-241.

CULFAZ M and YAGIZ M (2004) Ion exchange properties of natural clinoptilolite: lead-sodium and cadmium-sodium equilibria. Sep. Purif. Technol. 37 (2) 93-105.

EDERM E, KARAPINAR N and DONAT R (2004). The removal of heavy metal cations by natural zeolites. J. Colloid Interface Sci. 280 309-314.

FERNANDEZ A, RENDUELES M, RODRIGUES A and DIAZ M (1994) Co-ion behavior at high concentration cationic ion exchange. Ind. Eng. Chem. Res. 33 2789-2794.

GRADEV G, AVRAMOVA A and STEFANOVA I (1988) Silver(I) sorption on clinoptilolite and vermiculite and their modifications: In: Kallo D and Sherry HS (eds.) Occurrence, Properties and Utilizations of Natural Zeolites. Akadémiai Kiado, Budapest. 463-470.

INGLEZAKIS VJ and GRIGOROPOULOU H (2004) Effect of pore clogging on kinetics of lead uptake by clinoptilolite. J. Haz. Mater. B112 37-43.

INGLEZAKIS VJ, DIAMADIS NA, LOIZIDOU MD and GRIGOROPOULOU H P (1999) J. Colloid Interface Sci. 215 54-57.

KURAMA H, ZIMMER A and RESCHETILOWSKI W (2002) Chemical modification effect on the sorption capacity of natural clinoptilolite. Chem. Eng. and Technol. 25 (3) 301-305.

KURONEN M, WELLER M, TOWNSEND R and HARJULA R (2006) Ion exchange selectivity and structural changes in highly aluminous zeolites. React. Funct. Polym. 66 1350-1361.

KESRAOUI-OUKI S, CHEESEMAN R and PERRY R (1993) Effects of conditioning and treatment of chabazite and clinoptilolite prior to lead and cadmium removal. Environ. Sci. Technol. 27 1108-1116.

KESRAOUI-OUKI S, CHEESEMAN CR and PERRY R (1994) Natural zeolite utilisation in pollution control: A review of applications to metals' effluents. J. Chem. Technol. Biotechnol. $\mathbf{5 9}$ 121-126.

KOCASOY G AND SAHIN V (2007). Heavy metal removal from industrial wastewater by clinoptilolite. Environ. Sci. Health A 42 (14)_2139-2146.

KORKUNA O, LEBODA R, SKUBISZEWSKA-ZIEBA J, VRUBLEVS'KA T, GUN'KO VM and RYCZKOWSKI J (2006) Structural and physicochemical properties of natural zeolites: clinoptilolite and mordenite. Micropor. Mesopor. Mater. 87 243-254.

LANGWALDT J (2008) Ammonium removal from water by eight natural zeolites: a comparative study. Sep. Sci. Technol. 43 (8) 2166-2182.

MAMBA BB, NYEMBE DW and MULABA-BAFUBIANDI A F (2009). Removalof copper and cobalt from aqueous solutions using natural clinoptilolite. Water SA 35 307-314.

MCBRIDE MB (1980) Chemisorption of $\mathrm{Cd}^{2+}$ on calcite surfaces. Soil Sci. Soc. Am. J. 44 26-28.

MILAN Z, SANCHEZ E, WEILAND P, DE LAS POZAS C, BORJA R, MAYARI R and ROVIROSA N (1997) Ammonia removal from anerobically treated piggery manure by ion exchange in columns packed with homoionic zeolite. J. Chem. Eng. 66 65-71.

MISAELIDES PA, GODELITSAS A, FILIPPIDIS A, CHARISTOS D and ANOUSIS I (1995) Thorium and uranium uptake by natural zeolitic materials. Sci. Total Environ. 173/174 237-246.

MONDALE KD, CARLAND RM and APLAN FF (1995) The comparative ion exchange capacities of natural sedimentary and synthetic zeolites. Miner. Eng. 8 (4) 535-548.

NYEMBE DW, MAMBA BB AND MULABA AF (2010). Adsorption mechanisms of $\mathrm{Co}^{2+}$ and $\mathrm{Cu}^{2+}$ from aqueous dolutions using natural clinoptilolite: equilibrium and kinetic dtudies. J. Applied Sci. 10 (8) 599-610.

PANAYOTOVA M and VELIKOV B (2003) Influence of zeolite transformation in a homoionic form on the removal of some heavy metal ions from wastewater. J. Environ. Sci. Health A 38 (3) 545-554.

PANAYOTOVA MI (2001) Kinetics and thermodynamics of copper ions removal from wastewater by use of zeolite. Waste Manage. 21 671-676.

PAPACHRISTOU P, HARALAMBOUS KJ, LOIZIDOU M and SPYRELLIS N (1993) Studies on the nickel removal from aqueous solution. J. Environ. Sci. Health A 28 135-142.

RAHMANI AR, SAMADI MT and EHSANI HR (2009) Investigation of clinoptilolite natural zeolite regeneration by air stri pping followed by ion exchange for removal of ammonium from aqueous solutions. Iran. J. Environ. Health. Sci. Eng. 6 (3) 167-172.

REED BE and ARUNACHALAM S (1994) Removal of lead from aqueous solutions by condensed tannin gel adsorbent J. Environ. Eng. 120 (2) 416-436.

ROZIC M, STEFANOVIC SJ, KURAJICA S, MAEEFAT MR, MARGETA K and FARKAS A (2002) Ion exchange properties of natural clinoptilolite: lead-sodium and cadmium-sodium equilibria. J. Colloid Interface Sci. 284 48-56.

SEMMENS MJ and MARTIN WP (1988) The influence of pretreatment on the capacity and selectivity of clinoptilolite for metal ions. Water Research 22 (5) 537-542.

SEMMENS M, SEYFARTH IN, SAND LB and MUMPTON FA (1978) (eds.) (1996) Natural Zeolites. Occurrence, Properties and Use. Pergamon Press. Elmsford, NY. 517 pp.

SPRYNSKYY M, LEBEDYNETS M, TERZYK AP, KOWALCZYK $\mathrm{P}$, NAMIESNIK J and BUSZEWSKI B (2005) Ammonium sorption from aqueous solutions by the natural zeolite Transcarpathian clinoptilolite studied under dynamic conditions. J. Colloid Interface Sci. 284 408-415.

TRGO M, PERIC J and VUKOJEVIC MEDVIDOVIC N (2006) A comparative study of ion exchange kinetics in zinc/lead-modified zeolite-clinoptilolite systems. J. Haz. Mater. 136 (3) 938-945.

VASYLECHKO VO, GRYSHCHOUK GV, LEBEDYNETS LO, KUZ'MA YB, ZAKORDONSKIY VP, VASYLECHKO LO and KALYTOVS'KA MB (1999) Adsorption of cadmium on acidmodified Transcarpathian clinoptilolite. J. Chem. Anal. (Warsaw). 44 (6) 1013-1024.

VASYLECHKO VO, GRYSHCHOUK GV, KUZ'MA YU B, LEBEDYNETS LO and OLIYARNYK YA O (2000) Adsorption of cadmium on transcarpathian clinoptilolite. Adsorption Sci. Technol. 18 (7) 621-630.

ZACHARA JM, COWAN CE and RESCH CT (1991) Sorption of divalent metals on calcite. Geochim. Cosmochim. Acta 55 1549-1563.

ZAMZOW MJ, EICHBAUM BR, SANDGREN KR and SHANKS DE (1990) Heavy metal removal from motorway storm water using zeolites. Sep. Sci. Technol. 25 13-15.

ZAMZOW MJ and MURPHY JE (1992) Natural zeolites as cation exchangers for environmental protection. Sep. Sci. Technol. 1969-1984. 